\title{
Optimization of production of the anti-keratin 8 single-chain Fv TS1-218 in Pichia pastoris using design of experiments
}

\author{
Rozbeh Jafari, Birgitta E Sundström and Patrik Holm
}

\begin{abstract}
Background: Optimization of conditions during recombinant protein production for improved yield is a major goal for protein scientists. Typically this is achieved by changing single crucial factor settings one at a time while other factors are kept fixed through trial-and-error experimentation. This approach may introduce larger bias and fail to identify interactions between the factors resulting in failure of finding the true optimal conditions.

Results: In this study we have utilized design of experiments in order to identify optimal culture conditions with the aim to improve the final yield of the anti-keratin 8 ScFv TS1-218, during expression in P. pastoris in shake flasks. The effect of: $\mathrm{pH}$, temperature and methanol concentration on the yield of TS1-218 using buffered minimal medium was investigated and a predictive model established. The results demonstrated that higher starting $\mathrm{pH}$ and lower temperatures during induction significantly increased the yield of TS1-218. Furthermore, the result demonstrated increased biomass accumulation and cell viability at lower temperatures which suggested that the higher yield of TS1-218 could be attributed to lower protease activity in the culture medium. The optimal conditions ( $\mathrm{pH} 7.1$, temperature $11^{\circ} \mathrm{C}$ and methanol concentration 1.2\%) suggested by the predictive model yielded $21.4 \mathrm{mg}$ TS1-218 which is a 21-fold improvement compared to the yield prior to optimization.

Conclusion: The results demonstrated that design of experiments can be utilized for a rapid optimization of initial culture conditions and that P. pastoris is highly capable of producing and secreting functional single-chain antibody fragments at temperatures as low as $11^{\circ} \mathrm{C}$.
\end{abstract}

\section{Background}

Single-chain variable fragments (scFv) are small recombinant antibodies that consist of the variable binding domains of the light and heavy-chain $\left(\mathrm{V}_{\mathrm{L}}, \mathrm{V}_{\mathrm{H}}\right)$ joined together with a short peptide linker $[1,2]$. ScFvs retain the binding specificity of their parent immunoglobulins but are easier to manipulate and their expression is facilitated and can be readily expressed in different expression systems. During the last decades, the methylotropic yeast, Pichia pastoris (P. pastoris) has been proven to be a powerful candidate for high level expression of functional antibody fragments with reports of yields ranging from $10 \mathrm{mg}$ up to 4.88 gram per liter of culture [3-9]. P. pastoris is easier to manipulate and culture than other eukaryotic cells and is also capable of

\footnotetext{
* Correspondence: patrik.holm@kau.se
Department of Chemistry and Biomedical Sciences, Karlstad University, S-651

* Correspondence: patrik.holm@kau.se
Department of Chemistry and Biomedical Sciences, Karlstad University, S-651 88 Karlstad, Sweden
}

(c) 2011 Jafari et al; licensee BioMed Central Ltd. This is an Open Access article distributed under the terms of the Creative Commons Attribution License (http://creativecommons.org/licenses/by/2.0), which permits unrestricted use, distribution, and reproduction in any medium, provided the original work is properly cited. seen in higher eukaryotes such as disulfide bond formation, glycosylation and proteolytic processing. In addition, $P$. pastoris provides the possibility of extracellular secretion of recombinant proteins and the low level of secreted endogenous $P$. pastoris proteins enables easier purification of recombinant proteins [10]. Recently, we have utilized the $P$. pastoris $\mathrm{KM} 71 \mathrm{H}$ strain for overexpression of the anti-keratin $8 \mathrm{scFv}$ (TS1-218) in shake flasks where a twenty-fold increase in yield of soluble TS1-218 was obtained compared to overexpression of the same scFv in E. coli [11]. However, the yield of TS1218 from routine expression in $P$. pastoris using shake flasks could still become a substantial bottleneck for further progress due to the nature of shake flask cultures (i.e poor control).

Optimization of production conditions for overproduction of recombinant proteins are routinely achieved 
by varying single factors at a time until an apparent optimum is reached $[7,8,12]$. This approach could be labor intensive and assumes that all single parameters are mutually independent of one another and fails to identify interactions between the different factors involved [13]. The consequences could be failure in identifying the true optimal conditions for protein production. Recently, several groups have adopted the statistical design of experiments (DoE) methodology in order to address these limitations during optimization of the conditions in protein expression [14-18]. The major advantages of DoE are that interactions between multiple factors can be identified, and that a more reliable prediction of the true optimum can be achieved. In addition, a more structured approach towards experimental setup can be undertaken which can aid in reducing the number of experiments and facilitate data analysis. Today there are numerous software packages available which facilitate the application of DoE for nonstatisticians.

In this study we have applied DoE for optimization of the initial culture conditions in order to improve the final yield of the TS1-218 during expression in shake flask cultures by the P. pastoris KM71H Mut ${ }^{\mathrm{S}}$ strain. We have investigated whether yield of the TS1-218 can be improved without addition of supplementary compounds to the culture medium in order to facilitate downstream processing. Three factors; temperature, $\mathrm{pH}$ and methanol $(\mathrm{MeOH})$ concentration and their effects, alone and in combination, were investigated using response surface methodology (RSM) [13]. EnzymeLinked Immunosorbent Assay was used to assess the level of TS1-218 production.

\section{Methods}

\section{Cell strains and media}

P. pastoris strain $\mathrm{KM} 71 \mathrm{H} \mathrm{Mut}^{\mathrm{S}}$; arg4 aox $1:$ ARG4 (Invitrogen) expressing anti-keratin $8 \mathrm{scFv}, \mathrm{TS1}-218$. The $P$. pastoris clone, was maintained on Yeast extract Peptone Dextrose medium (YPD) agar plates $(1 \%(\mathrm{w} / \mathrm{v})$ yeast extract, $2 \%(\mathrm{w} / \mathrm{v})$ peptone, $2 \%(\mathrm{w} / \mathrm{v})$ dextrose, $1 \%(\mathrm{w} / \mathrm{v})$ agar). For biomass production, Buffered Minimal Glycerol medium (BMG; $100 \mathrm{mM}$ potassium phosphate $\mathrm{pH}$ $6.0,1.34 \%(\mathrm{w} / \mathrm{v})$ yeast nitrogen base, $4 \times 10^{-5} \%(\mathrm{w} / \mathrm{v})$ biotin, $1 \%(\mathrm{v} / \mathrm{v})$ glycerol) was used. Buffered Minimal Methanol medium (BMM; $100 \mathrm{mM}$ potassium phosphate $\mathrm{pH} 4-8,1.34 \%(\mathrm{w} / \mathrm{v})$ yeast nitrogen base, $4 \times 10^{-5} \%(\mathrm{w} / \mathrm{v})$ biotin, $0.1-3 \%(\mathrm{v} / \mathrm{v}) \mathrm{MeOH}$ was used for induction of protein expression.

\section{Experimental setup and analysis}

Temperature and $\mathrm{pH}$ are two of the most common crucial factors that can influence protein production in various expression systems as well as production of scFvs in $P$. pastoris $[7-9,19]$. $\mathrm{MeOH}$ concentration is another important factor in protein expression in $P$. pastoris under the regulation of the alcohol oxidase promoter (AOX) since $\mathrm{MeOH}$ can be used as the inducer and sole carbon source [20,21]. Consequently these three factors; temperature, $\mathrm{pH}$ and $\mathrm{MeOH}$ concentration were chosen as quantitative factors in our investigation. The absorbance values from ELISA assays were chosen as a response for the level of TS1-218 production. In the final experiments the viability of the $P$. pastoris cells and change in wet cell weight (WCW) were also used as responses.

Response surface methodology (RSM) using BoxBehnken design [22] with three levels for each factor was employed to evaluate their effects and interactions on TS1-218 yield. In a Box-Behnken design the investigated points are located at the midpoints of the edges of a cubical design region and at the center. The BoxBehnken design offers an advantage when investigating three factors as fewer numbers of experimental runs are required compared to other RSM designs [13]. MODDE software version 7.0.0.1 (Umetrics AB, Sweden) was used for experimental setup and data analysis. A total of 12 experimental runs with different combinations of the three factors and four replicates of the center point were carried out (Table 1).

Table 1 Box-Benhken design matrix and experimental results for the different factors and their effect on the responses

\begin{tabular}{cccccccc}
\hline Experiment & $\mathbf{p H}$ & $\begin{array}{c}\text { Temp } \\
{ }^{\circ} \mathrm{C}\end{array}$ & $\begin{array}{c}\text { MeOH } \\
\%\end{array}$ & ABS & $\begin{array}{c}\Delta \text { WCW } \\
(\%)\end{array}$ & $\begin{array}{c}\text { Viability } \\
\%\end{array}$ & pH $_{\text {final }}$ \\
\hline $\mathrm{N} 1$ & 6 & 10 & 1.25 & 0.66 & $+4,1$ & 99.73 & 5.2 \\
$\mathrm{~N} 2$ & 8 & 10 & 1.25 & 1.05 & $+2,2$ & 99.85 & 6.5 \\
$\mathrm{~N} 3$ & 6 & 20 & 1.25 & 0.10 & $-5,3$ & 99.02 & 5.1 \\
$\mathrm{~N} 4$ & 8 & 20 & 1.25 & 0.02 & $-1,0$ & 99.34 & 6.7 \\
$\mathrm{~N} 5$ & 6 & 15 & 0.5 & 0.45 & $-5,2$ & 99.56 & 4.5 \\
$\mathrm{~N} 6$ & 8 & 15 & 0.5 & 0.98 & $-1,5$ & 99.37 & 6.6 \\
$\mathrm{~N} 7$ & 6 & 15 & 2.0 & 0.75 & $-4,4$ & 99.62 & 5.0 \\
$\mathrm{~N} 8$ & 8 & 15 & 2.0 & 0.67 & $-1,8$ & 99.56 & 6.6 \\
$\mathrm{~N} 9$ & 7 & 10 & 0.5 & 1.13 & $+3,5$ & 99.45 & 6.2 \\
$\mathrm{~N} 10$ & 7 & 20 & 0.5 & 0.22 & $-5,0$ & 99.02 & 6.2 \\
$\mathrm{~N} 11$ & 7 & 10 & 2.0 & 1.07 & $+2,2$ & 99.67 & 6.3 \\
$\mathrm{~N} 12$ & 7 & 20 & 2.0 & 0.13 & $-5,2$ & 99.16 & 6.4 \\
$\mathrm{~N} 13^{*}$ & 7 & 15 & 1.25 & 1.16 & $-1,3$ & 99.68 & 6.3 \\
$\mathrm{~N} 14^{*}$ & 7 & 15 & 1.25 & 1.18 & $-1,1$ & 99.74 & 6.2 \\
$\mathrm{~N} 15^{*}$ & 7 & 15 & 1.25 & 1.12 & $-0,8$ & 99.63 & 6.2 \\
$\mathrm{~N} 16 *$ & 7 & 15 & 1.25 & 1.27 & $+1,2$ & 99.66 & 6.2 \\
\hline
\end{tabular}

${ }^{*}$ Centerpoint experiments.

Temp: temperature $\left({ }^{\circ} \mathrm{C}\right) ; \mathrm{MeOH}$ : methanol concentration $(\%, \mathrm{v} / \mathrm{v}) ; \mathrm{ABS}$ : absorbance at $405 \mathrm{~nm}$ with subtracted background $(650 \mathrm{~nm})$ reflecting TS1-218 yield; $\triangle \mathrm{WCW}$ : change in wet cell weight (\%) after $72 \mathrm{~h}$ of induction compared to WCW at start of induction (initial mean WCW: $564.4 \pm$ SD 0.006 $\mathrm{mg}) ; \mathrm{pH}_{\text {final }}$ : $\mathrm{pH}$ of the culture medium after $72 \mathrm{~h}$ of induction. 


\section{Expression of TS1-218}

Single $P$. pastoris colonies were grown overnight in BMG medium at $30^{\circ} \mathrm{C}$. The overnight culture was used to inoculate a larger volume of fresh BMG in baffled shake flasks (Nalgene). The cultures were grown until the cells reached log phase $\left(\mathrm{OD}_{600} 2-6\right)$. The cultures were then divided equally between conical sterile $50 \mathrm{~mL}$ tubes and centrifuged at $1500 \times \mathrm{g}$ for 5 minutes at room temperature and the supernatant was discarded and the wet cell weights (WCW) were measured (mean WCW: $564.4 \pm$ SD $0.006 \mathrm{mg})$. To induce protein expression the pellets were resuspended with $5 \mathrm{~mL}$ BMM to a final $\mathrm{OD}_{600}$ of $\sim 50$ and incubated for $72 \mathrm{~h}$ with vigorous shaking. Methanol was added (v/v) every $24 \mathrm{~h}$ to the cultures in order to maintain induction. The $\mathrm{MeOH}$ concentration and $\mathrm{pH}$ of the BMM medium and incubation temperatures varied depending on the experimental runs (Table 1). After $72 \mathrm{~h}$ of induction small samples were taken from the cultures for further analysis and the cultures were centrifuged at $3000 \times \mathrm{g}$ for 10 minutes at $4^{\circ} \mathrm{C}$. The culture supernatants were stored at $4^{\circ} \mathrm{C}$ and the WCWs were measured.

\section{Cell viability assay}

The viability of the $P$. pastoris cells were evaluated by propidium iodide (PI) staining [23]. Samples taken from the BMG cultures prior to induction and from each experimental run at the end point $(72 \mathrm{~h})$ of each experiment were diluted in phosphate buffered saline (PBS, $137 \mathrm{mM} \mathrm{NaCl}, 3 \mathrm{mM} \mathrm{KCl}, 8 \mathrm{mM} \mathrm{Na}_{2} \mathrm{HPO}_{4}$ and $1 \mathrm{mM}$ $\mathrm{KH}_{2} \mathrm{PO}_{4}, \mathrm{pH} 7.4$ ). The cells were stained with $\mathrm{PI}$ at a final concentration of $5 \mu \mathrm{g} / \mathrm{mL}$ for 10 minutes at room temperature. The samples were briefly centrifuged at $1500 \times \mathrm{g}$ and the supernatants were discarded. The cells were washed twice with PBS and finally analyzed in a BD FACScan ${ }^{\mathrm{TM}}$ flow cytometer (Becton Dickinson). A total count of 50000 cells was collected for each sample. PI negative cells were considered as viable cells and PI positive cells were regarded as dead. As a positive control, heat-killed P. pastoris cells were stained with PI as described above. As negative control, P. pastoris cells without PI staining were used.

\section{Enzyme Linked Immunosorbent Assay}

Microtiter 96 wells plates (Nunc) were coated over night at $4^{\circ} \mathrm{C}$ with $100 \mu \mathrm{L}$ per well of $5 \mu \mathrm{g} / \mathrm{mL}$ keratin $8 / 18 / 19$ complex in $0.1 \mathrm{mM} \mathrm{NaOH}$ [24]. The culture medium from different runs where diluted 60 times with (50 mM sodium phosphate buffer $\mathrm{pH} 6.5,350 \mathrm{mM}$ $\mathrm{NaCl}$ ) and added in triplicates with $100 \mu \mathrm{L}$ sample per well. The plates were incubated on a shaker for $2 \mathrm{~h}$ at room temperature. After washing with $50 \mathrm{mM}$ Tris- $\mathrm{HCl}$ $\mathrm{pH} 7.4,150 \mathrm{mM} \mathrm{NaCl}$ and $0.1 \%$ (v/v) Tween-20 (TBST) the plates were incubated for $2 \mathrm{~h}$ on a shaker at room temperature with $100 \mu \mathrm{L}$ per well $(0.85 \mu \mathrm{g} / \mathrm{mL})$ monoclonal mouse anti-polyhistidine-alkaline phosphatase conjugated antibody clone his-1 (Sigma-Aldrich) diluted with TBST. After washing with TBST the plates were developed with $3 \mathrm{mM}$ para-Nitro Phenyl Phosphate (pNPP) in $50 \mathrm{mM}$ 2-amino-2-metyl-1-propanol, $1 \mathrm{mM}$ $\mathrm{MgCl}_{2} \mathrm{pH} 10$. The absorbance was measured at $405 \mathrm{~nm}$ and the absorbance at $650 \mathrm{~nm}$ was subtracted. The mean absorbance for triplicate samples were calculated for the different runs before analysis in MODDE.

\section{Purification of TS1-218}

The hexahistidine-tagged TS1-218 from the scaled up one liter cultures were purified from the culture medium with immobilized-metal affinity chromatography (IMAC) using Ni-NTA agarose (Invitrogen). The TS1218 in the culture medium were allowed to bind to a $10 \mathrm{~mL} \mathrm{Ni-NTA}$ agarose gel bed in a K26/60 column (Pharmacia) followed by a wash of the Ni-NTA agarose gel bed with wash buffer (50 mM sodium phosphate buffer pH 6.5, $350 \mathrm{mM} \mathrm{NaCl}$ ) and another wash with a wash buffer containing $25 \mathrm{mM}$ imidazole. The TS1-218 was eluted with $50 \mathrm{mM}$ sodium phosphate buffer $\mathrm{pH}$ 6.5, $350 \mathrm{mM} \mathrm{NaCl}, 300 \mathrm{mM}$ imidazole. The samples were concentrated and the buffer was exchanged against wash buffer using Amicon Ultra-15 centrifugal filter units. BCA Protein Assay Kit (Pierce) was used to determine the concentration of TS1-218.

\section{SDS-PAGE}

The purified TS1-218 samples from the validations experiments were adjusted to equal volumes and separated on NuPage ${ }^{\circledR}$ Novex Bis-Tris 4-12\% polyacrylamide gels with NuPAGE ${ }^{\circledR}$ MES SDS Running Buffer according to the manufacturer's recommendations (Invitrogen) and stained with Coomassie Blue R-250.

\section{Results and Discussion}

The aim of this study was to identify optimal culture conditions for TS1-218 production in BMM medium in shake flasks by the methylotrophic yeast $P$. pastoris using design of experiments. There are many different factors that can influence protein expression in P. pastoris, such as $\mathrm{pH}$, temperature, $\mathrm{MeOH}$ concentration, cell density, medium composition or additives (casamino acids, sorbitol, EDTA) to name a few. In a previous study, $P$. pastoris $\mathrm{KM} 71 \mathrm{H} / \mathrm{Mut}^{\mathrm{S}}$ clones expressing hexahistidine-tagged (His-tagged) TS1-218 under the control of the AOX promoter were cultured in complex medium containing yeast extract and peptone at $\mathrm{pH} 6$, temperature $20^{\circ} \mathrm{C}$ and $0.5 \%(\mathrm{v} / \mathrm{v})$ methanol during expression [11]. Some components of the complex medium were retained in the metal affinity purification matrix and co-eluted with the TS1-218. These components interfered with the 
downstream processing of the purified proteins and needed to be removed prior to further analysis. Additives such as casamino acids and EDTA have been shown to increase the yield of secreted proteins in many cases $[7,25,26]$, probably due to their inhibitory effect on extracellular proteases present in the culture medium. However, these medium additives can also interfere with the purification matrix during affinity purification of Histagged proteins as mentioned earlier. For these reasons, buffered minimal medium without any supplementary additives which provides less background was used for both biomass production and protein induction in this study.

Generally, when using $P$. pastoris $\mathrm{Mut}^{\mathrm{S}}$ strains for protein production, high cell densities are used since the yield of secreted proteins are proportional to cell density [27]. In addition, the $\mathrm{Mut}^{\mathrm{S}}$ strains grow at a slower rate when methanol is used as the sole carbon source. However, very high cell densities can result in rapid depletion of the nutrients and lead to increased accumulation of extracellular protease activity due to increased cell death [20,27]. In contrast, in low cell density cultures more resources are employed for biomass production than protein production $[7,8]$. Therefore we decided to use a cell density $\left(\mathrm{OD}_{600}\right)$ of $\sim 50$ during the induction phase throughout the entire study.

Initially the effect of $\mathrm{pH}$, temperature and $\mathrm{MeOH}$ concentration were investigated using a wide range between the factor levels; $\mathrm{pH} 4-8$, temperature $15-30^{\circ} \mathrm{C}$ and $\mathrm{MeOH}$ concentration 0.1-3\%. However, at the highest temperature $\left(30^{\circ} \mathrm{C}\right)$ and lowest $\mathrm{pH}(\mathrm{pH} 4)$ investigated, no signal were detected in the ELISA assays for any of the experimental runs, nor were there any TS1-218 detected after Ni-NTA purification and SDS-PAGE analysis of the culture medium from these runs (results not shown). The results from the initial experiment indicated that lower temperatures and a more narrow range of the factors should be investigated in order to achieve a more comprehensive model.

In the second series of experiments, factor levels; $\mathrm{pH}$ 6-8, temperature $10-20^{\circ} \mathrm{C}$ and $\mathrm{MeOH}$ concentration of 0.5-2\% were investigated in a Box-Behnken design (Table 1). The absorbance data were fitted with multiple linear regression (MLR) which showed a statistically good model with a model validity of 0.86 which demonstrated that there were no lack of fit $(p>0.05)$. Model validity larger than 0.25 indicates that the model error is in the same range as the pure error and a model validity of 1 represents a perfect model. The model indicated that $99 \%$ of the absorbance response variation could be explained by the model $\left(R^{2}=0.99\right)$ and that $94 \%$ of the absorbance response variation could be predicted $\left(\mathrm{Q}^{2}=\right.$ 0.94). The reproducibility of the model (variation of the center point runs) was 0.98 . A reproducibility of 1.0

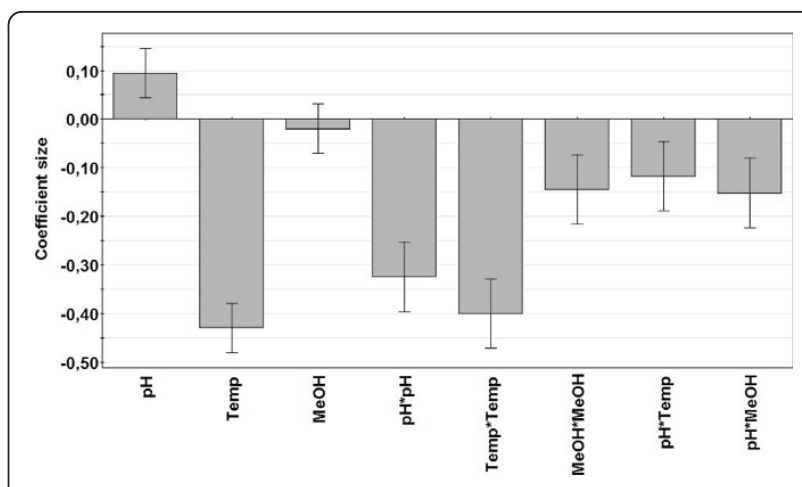

Figure 1 Coefficient plot of the ELISA ABS response. Coefficient plot with confidence intervals (error bars) showing the main $(\mathrm{pH}$, Temp, $\mathrm{MeOH}$ concentration), squared ( $\mathrm{pH}^{*} \mathrm{pH}$, Temp*Temp, $\left.\mathrm{MeOH}^{*} \mathrm{MeOH}\right)$ and interaction $\left(\mathrm{pH}^{*} \mathrm{Temp}, \mathrm{pH}^{*} \mathrm{MeOH}\right)$ effects of the investigated factors on the ELISA absorbance response. The significance level was set at 95\%. The significance of each term (factor) in the model is determined by the size of the coefficients (bars) and their error bars. Non-significant terms have an error bar that spans zero $(p>0.05)$. A negative coefficient for a main factor indicates that a decrease in that factor setting, relative to its center point, will have a positive effect on the yield of TS1-218 and consequently result in higher absorbance values. The interaction term temp* $\mathrm{MeOH}$ was not significant and was therefore removed from the model. The main term $\mathrm{MeOH}$ was also not significant, however, removing the term $\mathrm{MeOH}$ would also have removed the $\mathrm{MeOH}^{*} \mathrm{MeOH}$ and $\mathrm{pH}^{*} \mathrm{MeOH}$ terms which were significant.

indicates that the pure error is zero. The coefficient plot demonstrated that the main factors $\mathrm{pH}$ and temperature significantly influenced the yield of TS1-218 whereas different $\mathrm{MeOH}$ concentration did not influence the final TS1-218 yield (Figure 1). An interaction between $\mathrm{pH}$ and temperature as well as between $\mathrm{pH}$ and $\mathrm{MeOH}$ concentration could also be identified. Overall the model showed that the $\mathrm{pH}$ and temperature had the highest impact on TS1-218 yield as they presented the largest coefficients (Figure 1). The results obtained demonstrated that increasing the initial $\mathrm{pH}$ of the culture medium and decreasing temperature during induction resulted in higher absorbance values in the ELISA assays which reflect a higher TS1-218 concentration in the culture medium.

The correlation between the predictive and measured values for the ELISA absorbance values demonstrated an excellent parity and predictive capacity (Figure 2). The response surface plot of the ELISA absorbance response clearly indicated that lower temperature and higher initial $\mathrm{pH}$ should be employed when attempting to increase the yield of TS1-218 (Figure 3). According to the model an optimum for maximizing TS1-218 yield could be reached using BMM medium with a $\mathrm{pH}$ of 7.1, a $\mathrm{MeOH}$ concentration of $1.2 \%$ and a temperature of $11^{\circ} \mathrm{C}$ during induction. To validate the predicted optimum for maximum yield of TS1-218, cultures were 


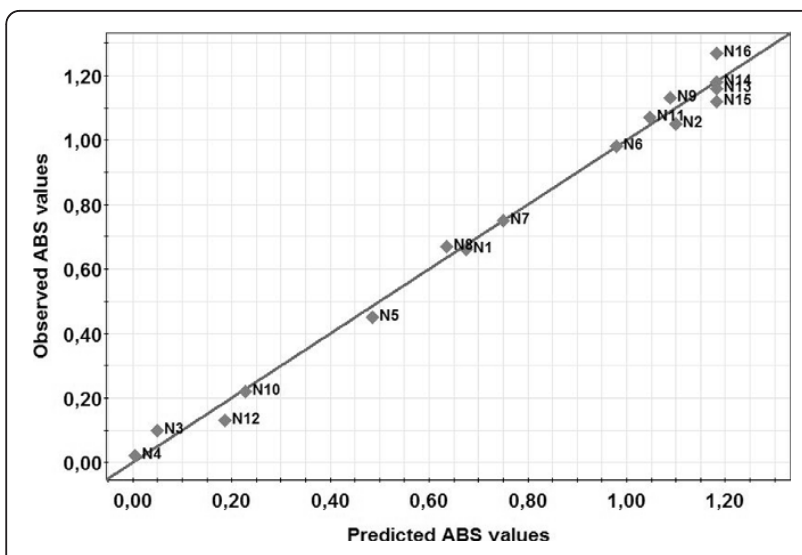

Figure 2 Demonstration of the predictive ability of the model The scatter plot shows the predicted versus measured experimental absorbance values. The fit to the line of parity was shown with $R^{2}=$ 0.99 which indicated that the regression model was able to predict output data with high reliability.

scaled up to 1 liter cultures in baffled shake flasks. This resulted in a yield of $21.4 \pm 1.25 \mathrm{mg}$ TS1-218 $(\mathrm{n}=3)$ at the optimal factor settings after purification which can be compared to $\sim 1 \mathrm{mg}$ TS1-218 obtained prior to optimization (Table 2). In addition, for comparison the fac-

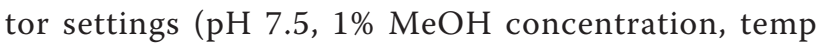
$15.5^{\circ} \mathrm{C}$ ) were investigated which yielded $15.3 \pm 1.3 \mathrm{mg}$ TS1-218 ( $\mathrm{n}=3)$ (Table 2). The observed results correlated with the predictions of the model regarding the TS1-218 production where an increased TS1-218 yield

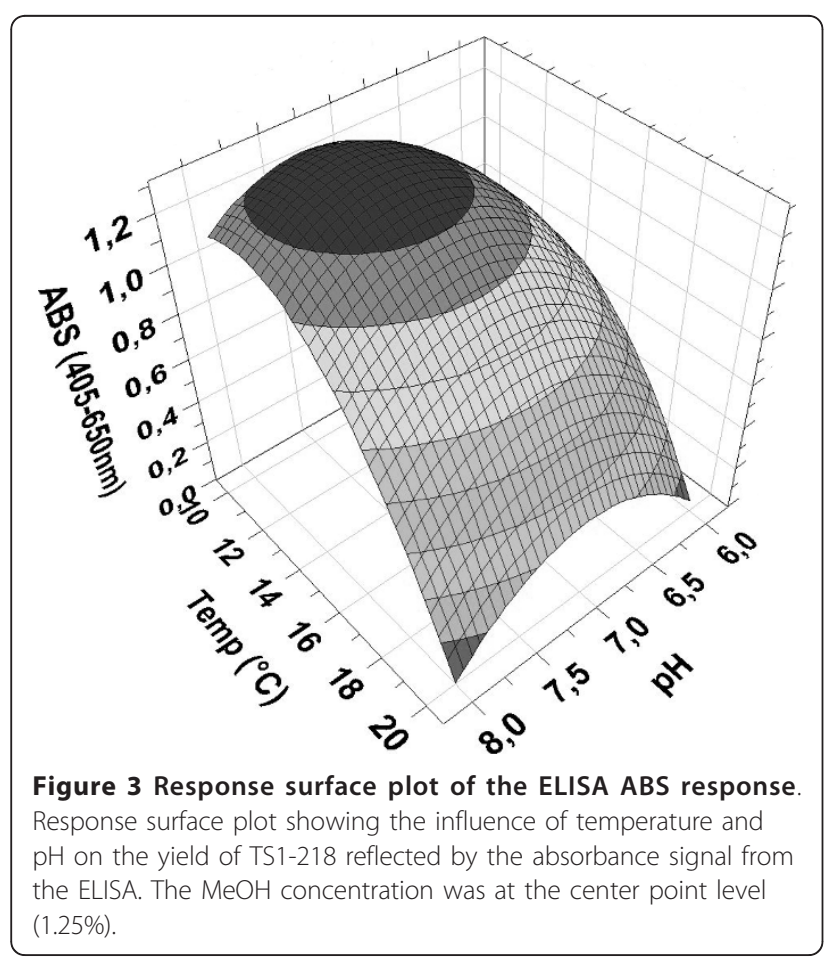

Table 2 Validation of the predicted optimal culture conditions for optimal TS1-218 yield in one liter cultures

\begin{tabular}{ccccc}
\hline Experiment & $\mathbf{p H}$ & $\mathrm{Temp}^{\circ} \mathbf{C}$ & $\mathbf{M e O H} \%$ & Yield $(\mathbf{m g})$ \\
\hline Pre-Optimization & 6 & 20 & 0.5 & $1.0 \pm 0.14$ \\
Reference & 7.5 & 15.5 & 1 & $15.3 \pm 1.29$ \\
Optimized & 7.1 & 11 & 1.2 & $21.4 \pm 1.25$ \\
\hline
\end{tabular}

Temp: temperature $\left({ }^{\circ} \mathrm{C}\right) ; \mathrm{MeOH}$ : methanol concentration (\%, v/v). Results are derived from three different experimental runs. Statistical significant difference was observed between every experiment with regard to the final yields $(p<0.05)$.

could be obtained. The samples from the validation experiments were analyzed using SDS-PAGE which demonstrated the higher yield after optimization of the culture conditions (Figure 4). The purity of the samples were in line with our previous study where a TS1-218 double band as well as a portion of glycosylated form of TS1-218 could be observed [11].

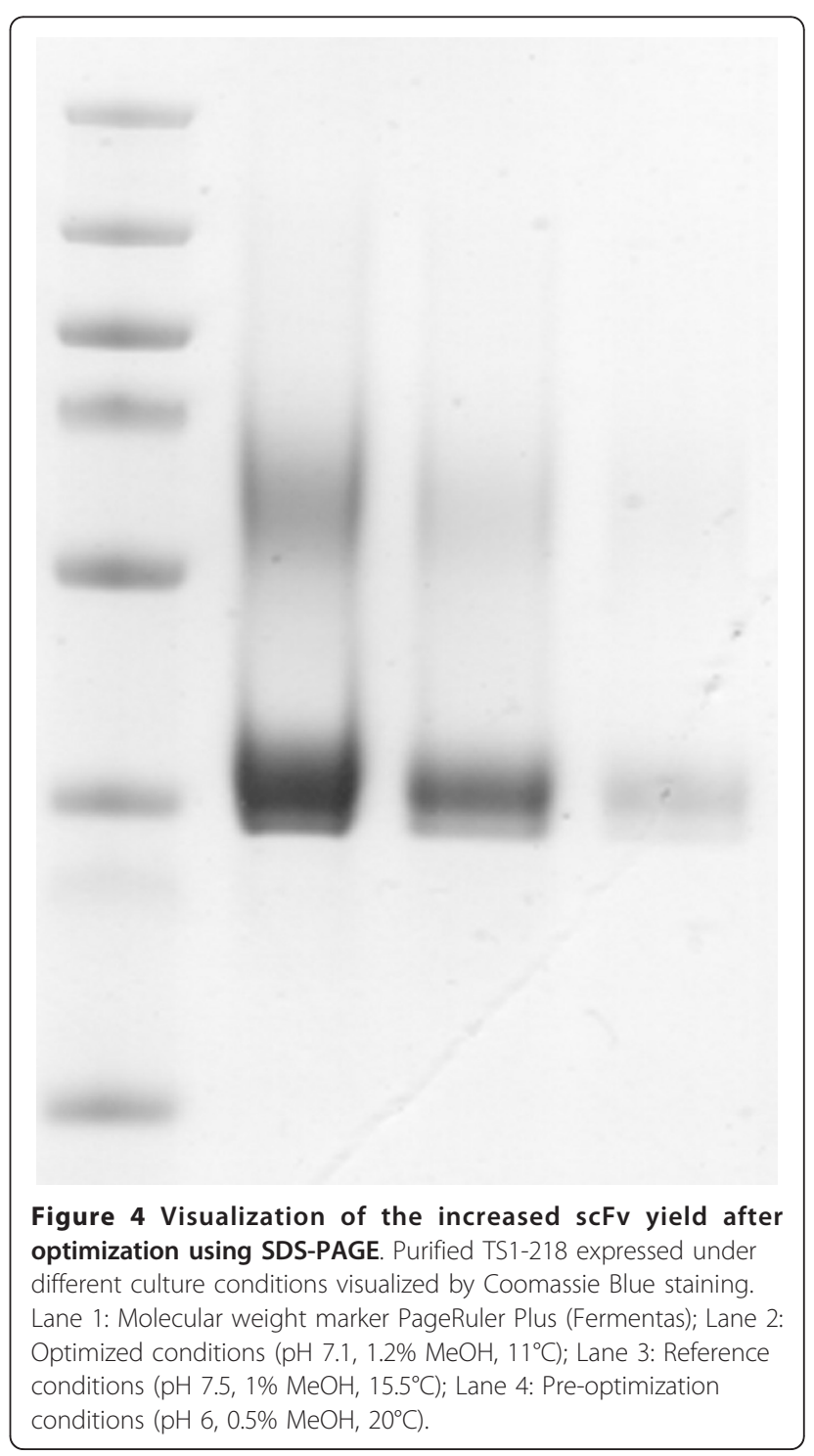


P. pastoris has several endogenous proteases although very little is known about these different proteases. Shi et al. [7] have described an increased production of a $\mathrm{scFv}$ at higher $\mathrm{pH}(7.5-8)$ in shake flask cultures, although the $\mathrm{scFv}$ production did not correlate with protease activity. Other studies have however shown that lower $\mathrm{pH}$ in the bioreactor cultures resulted in increased protease activity, which suggest that the majority of the proteases released by $P$. pastoris in these studies have an optimal activity at acidic conditions [28,29]. When measuring the $\mathrm{pH}$ in the culture medium after $72 \mathrm{~h}$ of induction it was found that the $\mathrm{pH}$ had decreased markedly in the different experimental runs even though a buffered medium was used (Table 1). It is likely that the TS1-218 was also subjected to increased proteolytic degradation in culture medium with lower $\mathrm{pH}$ resulting in weaker absorbance signal in the ELISA assays for the experimental runs with a lower starting $\mathrm{pH}$. This could probably be avoided if the $\mathrm{pH}$ in the cultures could be maintained at strict intervals by improving the buffer capacity in the culture medium or using bioreactors.

In a study by Dragosits et al. [30] no difference could be seen in the proteolytic activity in culture supernatants cultivated at different temperatures (20, 25 and $30^{\circ}$ C). On the contrary Hong et al. [28] have reported a decreased proteolytic activity in samples taken from fermentations performed at lower temperatures. In another study, Li et al. [31] reported that their recombinant protein was degraded after two days when expressed at $30^{\circ}$ $\mathrm{C}$ but not at $23^{\circ} \mathrm{C}$. This was attributed to lower amounts of extracellular protease in the culture medium due to increased cell viability at lower temperatures. It is commonly believed that intracellular $P$. pastoris proteases are released extracellularly upon death of the $P$. pastoris cells. When analyzing the viability of the $P$. pastoris cells after $72 \mathrm{~h}$ of induction the results demonstrated a higher viability at lower temperatures compared to the higher temperatures (Figure 5A). Although the viability of the P. pastoris cells did not decrease below 99\% for any of the experimental runs, temperature was shown to have a significant impact on the viability $(\mathrm{p}<0.05)$. This was in line with the change in wet cell weight (WCW) which demonstrated a statistically significant increase $(\mathrm{p}<0.05)$ at lower temperatures compared to higher temperatures where the WCW decreased (Figure 5B). The results showed that the cultures grew during the induction phase at lower temperatures $\left(10^{\circ} \mathrm{C}\right)$ with approximately $2-4 \%$ (Table 1 ). At higher temperatures there was in general a negative change in WCW, indicating cell death. The model showed that a concurrent increase in culture medium $\mathrm{pH}$ and decrease in incubation temperature resulted in stronger signals in the ELISA assay as well as an increase in WCW. The yield of TS1-218 increased when the temperature during induction was lowered from $20^{\circ} \mathrm{C}$ to $15^{\circ} \mathrm{C}$ and $10^{\circ} \mathrm{C}$. These results support the suggestions that lower temperatures decreases cellular death and thus decrease the release of proteases to the culture medium. Although, it cannot be excluded that the lower TS1-218 accumulation at lower $\mathrm{pH}$ and higher temperatures could be coupled to other mechanisms in addition to increased protease activity. Different environmental and metabolic conditions during recombinant protein expression induce numeral alterations in host intracellular processes, which are referred to as stress responses [32]. These stress responses can influence the cell metabolism, protein synthesis, folding and secretion mechanism and thus affect productivity of the hosts cells [32].

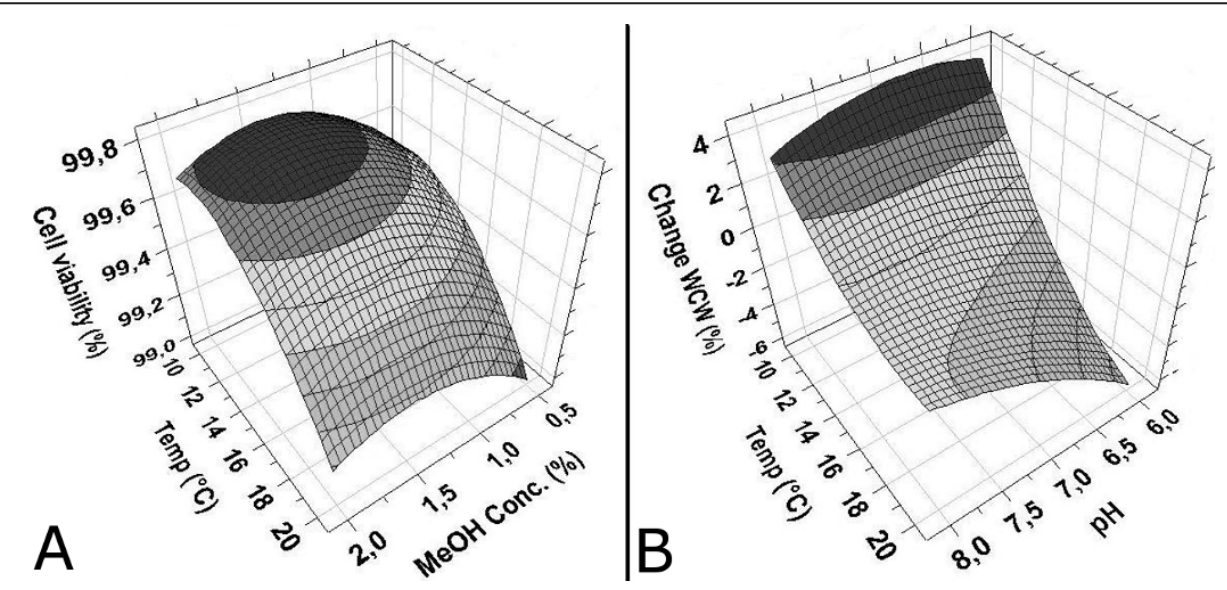

Figure 5 Response surface plots of the cell viability and WCW responses. Response surface plots of the optimization model showing the influence of temperature and $\mathrm{MeOH}$ concentration on the viability of the $P$. pastoris cells $(\mathbf{A})$ and the effect of temperature and $\mathrm{pH}$ on the biomass (i.e. change of WCW in \%) after $72 \mathrm{~h}$ of induction (B). The pH did not have a significant effect on the viability of the $P$. pastoris cells. The $\mathrm{MeOH}$ concentration of the response surface plot in panel B was at the center point level (1.25\%). 
Gasser et al. [33] have studied the influence of different cultivation temperatures on recombinant protein secretion and transcription of a set of key genes involved in various intracellular processes such as folding, secretion, DNA repair and amino acid synthesis to name a few. They speculated that lower temperatures reduce the amount of stress on the P. pastoris folding and secretory machinery enabling a higher production rate of correctly folded recombinant protein. Similar conclusions were made by Dragosits et al. [30] when they studied the effect of temperature on the proteome of P. pastoris. In a study by Jahic et al. [34] it was shown that lower temperature gave a 3.5 fold higher AOX activity which together with reduced proteolytic activity resulted in a two-fold increase in recombinant fusion protein production. It should be noted that the P. pastoris strains, promoters, culture medium and production techniques in these studies mentioned above differed from the ones employed in our study. It is however, plausible to assume that a combination of altered intracellular processes in the $P$. pastoris cells and a decreased protease release and activity could be responsible for the increased TS1-218 accumulation at higher $\mathrm{pH}$ and lower temperatures in our experiments. In our experiments the $\mathrm{MeOH}$ concentrations investigated did not have a significant influence on the final yield of TS1-218. This could be explained by the methanol utilization phenotype of our strain $\left(\mathrm{Mut}^{\mathrm{S}}\right)$ which utilizes methanol at a much slower rate compared to other methanol utilization phenotypes (i.e Mut ${ }^{+}$).

\section{Conclusions}

The aim of this study was to utilize DoE in order to investigate the effect of $\mathrm{pH}$, temperature and $\mathrm{MeOH}$ concentration on production of the anti-keratin 8 single-chain Fv, TS1-218, by P. pastoris strain KM71H/ $\mathrm{Mut}^{\mathrm{S}}$ with the purpose to optimize production. The application of DoE facilitated the experimental setup and data analysis and identified several interactions between the investigated factors. The model suggested several factor settings for optimal protein production that deviate considerably from the generally recommended conditions for recombinant protein expression in P. pastoris, specially the temperature. The yield of the TS1-218 was improved 21-fold compared to the preoptimization conditions $\left(\mathrm{pH} 6\right.$, temperature $20^{\circ} \mathrm{C}$, $\mathrm{MeOH}$ concentration $0.5 \%$ ) by lowering the temperature to $11^{\circ} \mathrm{C}$ and increasing the starting $\mathrm{pH}$ and $\mathrm{MeOH}$ concentration of the cultures to 7.1 and $1.2 \%(\mathrm{v} / \mathrm{v})$ respectively during induction. This study shows that $P$. pastoris is highly capable of producing recombinant proteins at temperatures as low as $11^{\circ} \mathrm{C}$.

\section{Acknowledgements}

The authors would like to thank Lars Renman at Karlstad University for valuable input.

\section{Authors' contributions}

$\mathrm{RJ}, \mathrm{BS}$ and PH directed and coordinated the study. RJ conducted all experimental procedures, data collection, analysis and interpretation and drafted the manuscript. BS and PH assisted with analysis and interpretation of the model. All authors approved the final version of the manuscript.

\section{Competing interests}

The authors declare that they have no competing interests.

Received: 22 December 2010 Accepted: 16 May 2011

Published: 16 May 2011

\section{References}

1. Bird RE, Hardman KD, Jacobson JW, Johnson S, Kaufman BM, Lee SM, Lee T, Pope SH, Riordan GS, Whitlow M: Single-chain antigen-binding proteins. Science 1988, 242:423-426.

2. Huston JS, Levinson D, Mudgett-Hunter M, Tai MS, Novotny J, Margolies MN, Ridge RJ, Bruccoleri RE, Haber E, Crea R, et al: Protein engineering of antibody binding sites: recovery of specific activity in an anti-digoxin single-chain $\mathrm{Fv}$ analogue produced in Escherichia coli. Proc Natl Acad Sci USA 1988, 85:5879-5883.

3. Chang HJ, Choi SW, Chun HS: Expression of functional single-chain variable domain fragment antibody (scFv) against mycotoxin zearalenone in Pichia pastoris. Biotechnol Lett 2008, 30:1801-1806.

4. Eldin P, Pauza ME, Hieda Y, Lin G, Murtaugh MP, Pentel PR, Pennell CA: High-level secretion of two antibody single chain Fv fragments by Pichia pastoris. J Immunol Methods 1997, 201:67-75.

5. Freyre FM, Vazquez JE, Ayala M, Canaan-Haden L, Bell H, Rodriguez I, Gonzalez A, Cintado A, Gavilondo JV: Very high expression of an anticarcinoembryonic antigen single chain $\mathrm{Fv}$ antibody fragment in the yeast Pichia pastoris. J Biotechnol 2000, 76:157-163.

6. Rahbarizadeh F, Rasaee MJ, Forouzandeh M, Allameh AA: Over expression of anti-MUC1 single-domain antibody fragments in the yeast Pichia pastoris. Mol Immunol 2006, 43:426-435.

7. Shi $X$, Karkut $T$, Chamankhah M, Alting-Mees M, Hemmingsen SM, Hegedus D: Optimal conditions for the expression of a single-chain antibody (scFv) gene in Pichia pastoris. Protein Expr Purif 2003, 28:321-330.

8. Wan L, Cai H, Yang H, Lu Y, Li Y, Li X, Li S, Zhang J, Cheng J, Lu X: Highlevel expression of a functional humanized single-chain variable fragment antibody against CD25 in Pichia pastoris. Appl Microbiol Biotechnol 2008, 81:33-41.

9. Damasceno LM, Pla I, Chang HJ, Cohen L, Ritter G, Old LJ, Batt CA: An optimized fermentation process for high-level production of a singlechain Fv antibody fragment in Pichia pastoris. Protein Expr Purif 2004, 37:18-26.

10. Cregg JM, Vedvick TS, Raschke WC: Recent advances in the expression of foreign genes in Pichia pastoris. Biotechnology (N Y) 1993, 11:905-910.

11. Jafari R, Holm P, Piercecchi M, Sundstrom BE: Construction of divalent anti-keratin 8 single-chain antibodies (sc(Fv)(2)), expression in Pichia pastoris and their reactivity with multicellular tumor spheroids. J Immunol Methods 2011, 364:65-76.

12. Cai H, Chen L, Wan L, Zeng L, Yang H, Li S, Li Y, Cheng J, Lu X: High-level expression of a functional humanized anti-CTLA4 single-chain variable fragment antibody in Pichia pastoris. Appl Microbiol Biotechnol 2009, 82:41-48.

13. Eriksson L: Design of experiments : principles and applications Umea: Umetrics; 2000.

14. Chambers SP, Swalley SE: Designing experiments for high-throughput protein expression. Methods Mol Biol 2009, 498:19-29.

15. Holmes WJ, Darby RA, Wilks MD, Smith R, Bill RM: Developing a scalable model of recombinant protein yield from Pichia pastoris: the influence of culture conditions, biomass and induction regime. Microb Cell Fact 2009, 8:35.

16. Islam RS, Tisi D, Levy MS, Lye GJ: Framework for the rapid optimization of soluble protein expression in Escherichia coli combining microscale experiments and statistical experimental design. Biotechnol Prog 2007, 23:785-793. 
17. Lin $\mathrm{H}$, Kim $\mathrm{T}$, Xiong $\mathrm{F}$, Yang $\mathrm{X}$ : Enhancing the production of $\mathrm{Fc}$ fusion protein in fed-batch fermentation of Pichia pastoris by design of experiments. Biotechnol Prog 2007, 23:621-625.

18. Swalley SE, Fulghum JR, Chambers SP: Screening factors effecting a response in soluble protein expression: formalized approach using design of experiments. Anal Biochem 2006, 351:122-127.

19. Tanfous NGB, Kallel H, Jarbouia MA, Fathallah DM: Expression in Pichia pastoris of a recombinant scFv form of MAb 107, an anti human CD11b integrin antibody. Enzyme and microbal technology 2005, 38:636-642.

20. Daly R, Hearn MT: Expression of heterologous proteins in Pichia pastoris: a useful experimental tool in protein engineering and production. $J \mathrm{Mol}$ Recognit 2005, 18:119-138.

21. Cereghino JL, Cregg JM: Heterologous protein expression in the methylotrophic yeast Pichia pastoris. FEMS Microbiol Rev 2000, 24:45-66.

22. Box G, Behnken D: Some new three level designs for the study of quantitative variables. In Technometrics. Volume 2. Richmond, Va : American Society for Quality Control ; Richmond, Va: American Statistical Association, 1959; 1960:455-475.

23. Zhao HL, Xue C, Wang Y, Yao XQ, Liu ZM: Increasing the cell viability and heterologous protein expression of Pichia pastoris mutant deficient in PMR1 gene by culture condition optimization. Appl Microbiol Biotechnol 2008, 81:235-241.

24. Sundstrom BE, Nathrath WB, Stigbrand TI: Diversity in immunoreactivity of tumor-derived cytokeratin monoclonal antibodies. J Histochem Cytochem 1989, 37:1845-1854.

25. Sreekrishna K, Brankamp RG, Kropp KE, Blankenship DT, Tsay JT, Smith PL, Wierschke JD, Subramaniam A, Birkenberger LA: Strategies for optimal synthesis and secretion of heterologous proteins in the methylotrophic yeast Pichia pastoris. Gene 1997, 190:55-62.

26. Clare JJ, Romanos MA, Rayment FB, Rowedder JE, Smith MA, Payne MM Sreekrishna K, Henwood CA: Production of mouse epidermal growth factor in yeast: high-level secretion using Pichia pastoris strains containing multiple gene copies. Gene 1991, 105:205-212.

27. Cregg JM, Cereghino JL, Shi J, Higgins DR: Recombinant protein expression in Pichia pastoris. Mol Biotechnol 2000, 16:23-52.

28. Hong F, Meinander NQ, Jonsson LJ: Fermentation strategies for improved heterologous expression of laccase in Pichia pastoris. Biotechnol Bioeng 2002, 79:438-449.

29. Kobayashi K, Kuwae S, Ohya T, Ohda T, Ohyama M, Ohi H, Tomomitsu K, Ohmura T: High-level expression of recombinant human serum albumin from the methylotrophic yeast Pichia pastoris with minimal protease production and activation. J Biosci Bioeng 2000, 89:55-61.

30. Dragosits M, Stadlmann J, Albiol J, Baumann K, Maurer M, Gasser B, Sauer M, Altmann F, Ferrer P, Mattanovich D: The effect of temperature on the proteome of recombinant Pichia pastoris. J Proteome Res 2009, 8:1380-1392

31. Li Z, Xiong F, Lin Q, d'Anjou M, Daugulis AJ, Yang DS, Hew CL: Lowtemperature increases the yield of biologically active herring antifreeze protein in Pichia pastoris. Protein Expr Purif 2001, 21:438-445.

32. Mattanovich D, Gasser B, Hohenblum H, Sauer M: Stress in recombinant protein producing yeasts. J Biotechnol 2004, 113:121-135.

33. Gasser B, Maurer M, Rautio J, Sauer M, Bhattacharyya A, Saloheimo M, Penttila M, Mattanovich D: Monitoring of transcriptional regulation in Pichia pastoris under protein production conditions. BMC Genomics 2007, 8:179.

34. Jahic M, Wallberg F, Bollok M, Garcia P, Enfors SO: Temperature limited fed-batch technique for control of proteolysis in Pichia pastoris bioreactor cultures. Microb Cell Fact 2003, 2:6.

doi:10.1186/1475-2859-10-34

Cite this article as: Jafari et al:: Optimization of production of the antikeratin 8 single-chain Fv TS1-218 in Pichia pastoris using design of experiments. Microbial Cell Factories 2011 10:34.

\section{Submit your next manuscript to BioMed Central and take full advantage of:}

- Convenient online submission

- Thorough peer review

- No space constraints or color figure charges

- Immediate publication on acceptance

- Inclusion in PubMed, CAS, Scopus and Google Scholar

- Research which is freely available for redistribution

Submit your manuscript at www.biomedcentral.com/submit
Biomed Central 